Article

\title{
Design for Novel Hot-Work Die Steel by Thermodynamic Calculation and Microstructural Examination
}

\author{
Zunjun Zhang ${ }^{1}$, Jishan Zhang ${ }^{1}$, Zhihao Yao ${ }^{2}$, Guoliang Xie ${ }^{1}$, Yong Lian ${ }^{3} \mathbb{D}$, Minyu $\mathrm{Ma}^{3}$, \\ Chao Zhao ${ }^{3}$ and Jinfeng Huang ${ }^{1, *}$ \\ 1 State Key Laboratory for Advanced Metals and Materials, University of Science and Technology Beijing, \\ Beijing 100083, China \\ 2 School of Materials Science and Engineering, University of Science and Technology Beijing, \\ Beijing 100083, China \\ 3 Institute for Advanced Materials and Technology, University of Science and Technology Beijing, \\ Beijing 100083, China \\ * Correspondence: ustbjinfeng_huang@163.com; Tel.: +86-010-62334928
}

Received: 26 June 2019; Accepted: 18 July 2019; Published: 22 July 2019

\begin{abstract}
In this paper, a new type of hot-work die steel with excellent high-temperature mechanical properties at $700{ }^{\circ} \mathrm{C}$ was designed based on the traditional $25 \mathrm{Cr} 3 \mathrm{Mo} 3 \mathrm{NiNb}$ steel with the help of Thermo-calc software. The effects of C, Cr, Mo, W and V on the types and mass fractions of carbides were studied. Phase diagram calculation revealed that with the increase of $\mathrm{V}$ and $\mathrm{W}$ contents and the decrease of $\mathrm{Cr}$ content, the precipitation temperature and the mass fraction of $\mathrm{M}_{23} \mathrm{C}_{6}$ carbides decreased. Meanwhile, the mass fraction of MC carbides increased as the Mo content decreased. Based on the thermodynamic calculation, new material 25Cr3Mo2NiWVNb steel was designed. Compared to the $25 \mathrm{Cr} 3 \mathrm{Mo} 3 \mathrm{NiNb}$ steel, more finely dispersed $\mathrm{MC}$ and $\mathrm{M}_{2} \mathrm{C}$ carbides with high thermal stability, as well as fewer $\mathrm{M}_{23} \mathrm{C}_{6}$ carbides with low thermal stability, were precipitated in the new steel. The high-temperature tensile showed that the new steel showed high thermal stability and strength even at $700{ }^{\circ} \mathrm{C}$. The high-temperature strengthening effect might be ascribed to the fine and stable nano-scale $\mathrm{MC}$ and $\mathrm{M}_{2} \mathrm{C}$ carbides which precipitated during tempering.
\end{abstract}

Keywords: alloy design; hot-work die steel; high-temperature strength; nanocarbide; thermodynamic calculation

\section{Introduction}

Hot working dies have been widely used in the field of machining techniques. With the development of modern industry toward higher efficiency and better precision, the hot work die steel with excellent performance has received extensive attention [1-4]. In addition to mechanical stress during the die filling process, such as die casting, hot extrusion, hot forging and hot stamping, hot-work die steel also endures rapid heating and cooling impact when interacting with hot metals due to the extremely harsh and complex working environment $[5,6]$. The high-temperature conditions can influence the material microstructure significantly, which always deteriorates mechanical properties [7-9]. The service life of the traditional hot-work dies is limited by insufficient high-temperature performance (especially high-temperature strength), leading to collapse and deformation. In order to prolong the service life of hot-work die steel, it is necessary to enhance high-temperature strength of die steel.

The high-temperature strength of hot work die steel can be enhanced by increasing carbon and alloying element content and micro-alloying, such as $\mathrm{V}, \mathrm{Nb}$, Ti and $\mathrm{N}$ elements $[10,11]$. Consequently, various type of carbides will precipitate in the matrix after tempering. The $\mathrm{MC}, \mathrm{M}_{2} \mathrm{C}$, and $\mathrm{M}_{6} \mathrm{C}$ carbides 
have a simple crystal structure with a high melting point and a high hardness [3,12]. These carbides have been reported to be beneficial to improving the hardness and toughness of die steel due to their high hardness and thermal stability. According to [13], a large amount of $\mathrm{M}_{2} \mathrm{C}$ carbides are precipitated in steel at around $720^{\circ} \mathrm{C}$, which provides a good strengthening effect. However, the $\mathrm{M}_{7} \mathrm{C}_{3}$ and $\mathrm{M}_{23} \mathrm{C}_{6}$ carbides have poor thermal stability and tend to grow up at high temperature, resulting in the deterioration of mechanical properties $[3,12,14,15]$. Despite the enhancement of high-temperature strength, its mechanical properties, such as toughness and fatigue performance, decreased significantly, which could be attributed to the coarsening carbides and the high-carbon martensite phase with needle sharp obtained after quenching. Therefore, the traditional methods can hardly achieve the high-temperature strength and the mechanical properties of hot-work die steel simultaneously.

To this end, this work developed new steel based on the "low-carbon low-alloy" design. The effects of alloy elements on the precipitation of carbides were evaluated by phase diagram calculation. Through the reasonable combination of alloying elements, the precipitation of the highly dispersed, nano-scaled, and thermal stable carbides like $\mathrm{MC}$ and $\mathrm{M}_{2} \mathrm{C}$ rather than the $\mathrm{M}_{23} \mathrm{C}_{6}$ carbides was promoted after quenching and tempering, so that the lack of high-temperature strength caused by low alloy solution can be overcome.

\section{Materials and Methods}

\subsection{Phase Diagram Calculation and Alloy Design}

Table 1 shows the chemical composition of the traditional low-carbon low-alloy hot-work die steel $25 \mathrm{Cr} 3 \mathrm{Mo} 3 \mathrm{NiNb}$. Based on the composition of the alloy, Thermo-calc software (TCFE6, University of Science and Technology Beijing, Beijing, China) was used to optimize alloying elements and high-temperature strength of the alloy. Since the mechanical properties of hot-work die steels are closely related to the carbides in the steel, it is necessary to study the existing carbide-forming elements $\mathrm{Cr}$ and $\mathrm{Mo}$ in the $25 \mathrm{Cr} 3 \mathrm{Mo} 3 \mathrm{NiNb}$ steel. $\mathrm{Cr}$, as a constituent element of $\mathrm{Cr}_{23} \mathrm{C}_{6}$, determines the thermal stability [10]. Mo is the main component of $\mathrm{M}_{2} \mathrm{C}$ carbide, which is important reinforcement for hot-work die steel. Additionally, $\mathrm{V}$ is not contained in the alloy, but it has a significant effect on the precipitation of carbides' type, size and chemical composition. Although W is less able to form carbides, it will provide a good solid solution strengthening effect $[4,16,17]$. The calculation results in Figure 1 show that there are mainly three kinds of carbides, namely, $\mathrm{MC}, \mathrm{M}_{6} \mathrm{C}$, and $\mathrm{M}_{23} \mathrm{C}_{6}$ carbides in the steel. Some carbides in the steel are not reflected in the calculation, such as the non-equilibrium phases $\mathrm{M}_{2} \mathrm{C}$ and $\mathrm{M}_{7} \mathrm{C}_{3}$. Therefore, by calculating the influence of various alloying elements on the type and quantity of carbide precipitation in $25 \mathrm{Cr} 3 \mathrm{Mo} 3 \mathrm{NiNb}$ steel, a reference can be provided for the optimization of alloying elements, thus designing a new alloy with higher high-temperature strength.

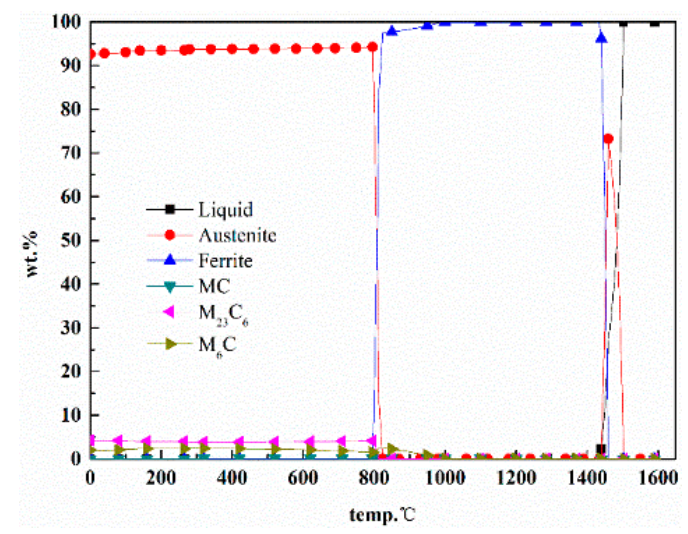

Figure 1. Thermodynamic calculation results for $25 \mathrm{Cr} 3 \mathrm{Mo} 3 \mathrm{NiNb}$. 
Table 1. Chemical composition of $25 \mathrm{Cr} 3 \mathrm{Mo} 3 \mathrm{NiNb}$ for phase diagram calculation.

\begin{tabular}{cccccc}
\hline Elements & $\mathbf{C}$ & $\mathbf{N i}$ & $\mathbf{C r}$ & $\mathbf{M o}$ & $\mathbf{N b}$ \\
\hline $\mathrm{wt} \%$ & 0.25 & 0.65 & 3 & 3 & 0.1 \\
\hline
\end{tabular}

\subsection{Experimental Materials}

The designed $25 \mathrm{Cr} 3 \mathrm{Mo} 2 \mathrm{NiWVNb}$ steel and the comparative steel $(25 \mathrm{Cr} 3 \mathrm{Mo} 3 \mathrm{NiNb})$ were first melted in a vacuum induction furnace and then casted into $25 \mathrm{~kg}$ ingots. The composition design process of the new alloy will be described later. The chemical compositions are shown in Tables 2 and 3 . The ingot was heated to $1130^{\circ} \mathrm{C}$ and hot-forged into a rod with a size of $\varphi=30 \mathrm{~mm}$, and then annealed at $700{ }^{\circ} \mathrm{C}$ for $24 \mathrm{~h}$ to relief stress. Afterwards, it was cooled to $500{ }^{\circ} \mathrm{C}$ with furnace, and cooled to room temperature in the air.

Table 2. 25Cr3Mo2NiWVNb steel composition (mass fraction, \%).

\begin{tabular}{ccccccccc}
\hline Elements & $\mathbf{C}$ & $\mathbf{N i}$ & $\mathbf{C r}$ & $\mathbf{M o}$ & $\mathbf{V}$ & $\mathbf{W}$ & $\mathbf{N b}$ & $\mathbf{F e}$ \\
\hline Chemical compositions & 0.29 & 1.45 & 2.50 & 2.18 & 0.46 & 0.58 & 0.05 & Bal. \\
\hline
\end{tabular}

Table 3. $25 \mathrm{Cr} 3 \mathrm{Mo} 3 \mathrm{NiNb}$ steel composition (mass fraction, \%).

\begin{tabular}{ccccccc}
\hline Elements & $\mathbf{C}$ & $\mathbf{N i}$ & $\mathbf{C r}$ & $\mathbf{M o}$ & $\mathbf{N b}$ & $\mathbf{F e}$ \\
\hline Chemical compositions & 0.28 & 0.65 & 3.00 & 2.9 & 0.08 & Bal. \\
\hline
\end{tabular}

Heat treatment, including annealing, quenching and tempering, is given in Table 4. After heat treatment, the material was processed into a standard high-temperature tensile test sample. The tensile test was performed on a UH-2000 model stretching machine (University of Science and Technology Beijing, Beijing, China) at $700{ }^{\circ} \mathrm{C}$, which is the usual temperature reached by the mold surface. Figure 2 shows the drawing of the specimen used for high-temperature tensile test.

Table 4. Heat treatment process of test steels.

\begin{tabular}{cl}
\hline Heat Treatment Process & \multicolumn{1}{c}{ Heat Treatment Process System } \\
\hline Annealing process & $\begin{array}{l}\text { Annealed at } 870{ }^{\circ} \mathrm{C} \text { for } 2 \mathrm{~h} \text {, cooled to } 500^{\circ} \mathrm{C} \text { at a cooling rate of } 30{ }^{\circ} \mathrm{C} / \mathrm{h}, \\
\text { and then cooled down to room temperature in the air } \\
\text { Austenitization temperature at } 1020{ }^{\circ} \mathrm{C} \text { holding for } 1 \mathrm{~h} \text {, followed by an } \\
\text { immediate water-quench to room temperature }\end{array}$ \\
Quenching process & $\begin{array}{l}\text { Tempered at } 640{ }^{\circ} \mathrm{C} \text { for } 2.5 \mathrm{~h} \text { after quenching, cooled down to room } \\
\text { temperature in the air }\end{array}$ \\
\hline
\end{tabular}

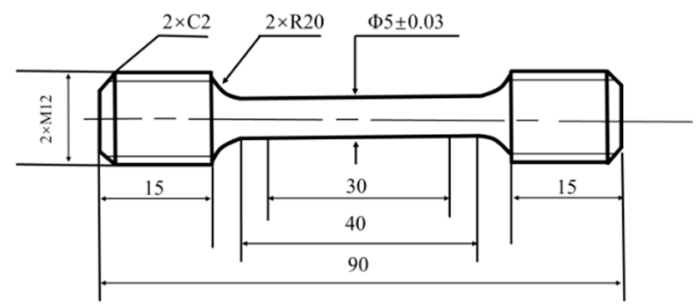

Figure 2. The drawing of high-temperature tensile specimen. (mm)

The thin foil for TEM observation were cut into foil $0.3 \mathrm{~mm}$ thick from the heat-treated steel, mechanically thinned to about $50 \mu \mathrm{m}$, and double-jet electropolished with $5 \%$ perchloric acid alcohol solution. The samples were observed by JEOL 2100 TEM (General Research Institute for Nonferrous Metals, Beijing, China). 


\subsection{The Process of Phase Diagram Calculation and Alloy Design}

Table 1 shows the chemical composition of the traditional low-carbon low-alloy hot-work die steel $25 \mathrm{Cr} 3 \mathrm{Mo} 3 \mathrm{NiNb}$. Based on the alloy composition, the effects of alloying elements $(\mathrm{V}, \mathrm{W}, \mathrm{Mo}, \mathrm{Cr}, \mathrm{C})$ on the type and mass fraction of the equilibrium precipitated phases were calculated from $0{ }^{\circ} \mathrm{C}$ to $1600{ }^{\circ} \mathrm{C}$.

\subsubsection{Effects of Elements on $\mathrm{M}_{23} \mathrm{C}_{6}$ Carbides}

Thermo-calc software was used to carry out thermodynamic calculation of equilibrium precipitation. According to the simulation results (Figure 3), the quantity of $\mathrm{M}_{23} \mathrm{C}_{6}$ carbide decreases as the mass fractions of $\mathrm{V}, \mathrm{W}$ and Mo increase, indicating that $\mathrm{V}, \mathrm{W}$, and Mo inhibit the formation of $\mathrm{M}_{23} \mathrm{C}_{6}$ carbides. Meanwhile, with the increase of $\mathrm{Cr}$ and $\mathrm{C}$ mass fractions, the quantity of $\mathrm{M}_{23} \mathrm{C}_{6}$ carbides increases, showing that $\mathrm{Cr}$ and $\mathrm{C}$ elements can promote the formation of $\mathrm{M}_{23} \mathrm{C}_{6}$ carbides.
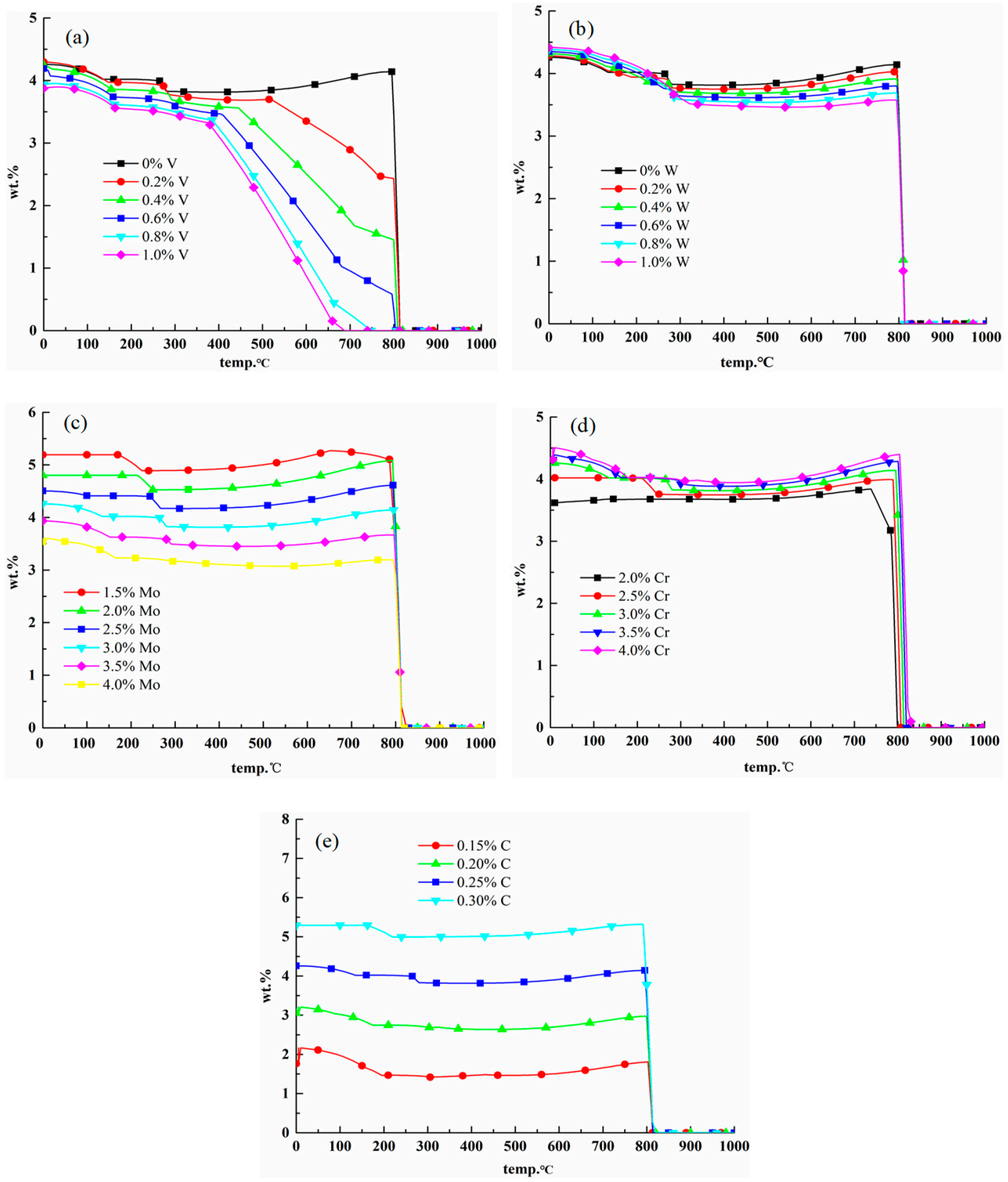

Figure 3. Effects of alloying elements on $\mathrm{M}_{23} \mathrm{C}_{6}$ carbides. (a) Effect of $\mathrm{V}$ on $\mathrm{M}_{23} \mathrm{C}_{6}$; (b) effect of $\mathrm{W}$ on $\mathrm{M}_{23} \mathrm{C}_{6}$; (c) effect of Mo on $\mathrm{M}_{23} \mathrm{C}_{6}$; (d) effect of $\mathrm{Cr}$ on $\mathrm{M}_{23} \mathrm{C}_{6}$; (e) effect of $\mathrm{C}$ on $\mathrm{M}_{23} \mathrm{C}_{6}$. 


\subsubsection{Effects of Elements on $\mathrm{M}_{6} \mathrm{C}$ Carbides}

As shown in Figure 4, the formation of $\mathrm{M}_{6} \mathrm{C}$ carbides is promoted by $\mathrm{V}$ below $500{ }^{\circ} \mathrm{C}$, but suppressed above $500{ }^{\circ} \mathrm{C}$. Overall, Mo and $\mathrm{W}$ elements promote the formation of $\mathrm{M}_{6} \mathrm{C}$ carbides, and $\mathrm{Cr}$ element promotes the formation of $\mathrm{M}_{6} \mathrm{C}$ carbides.
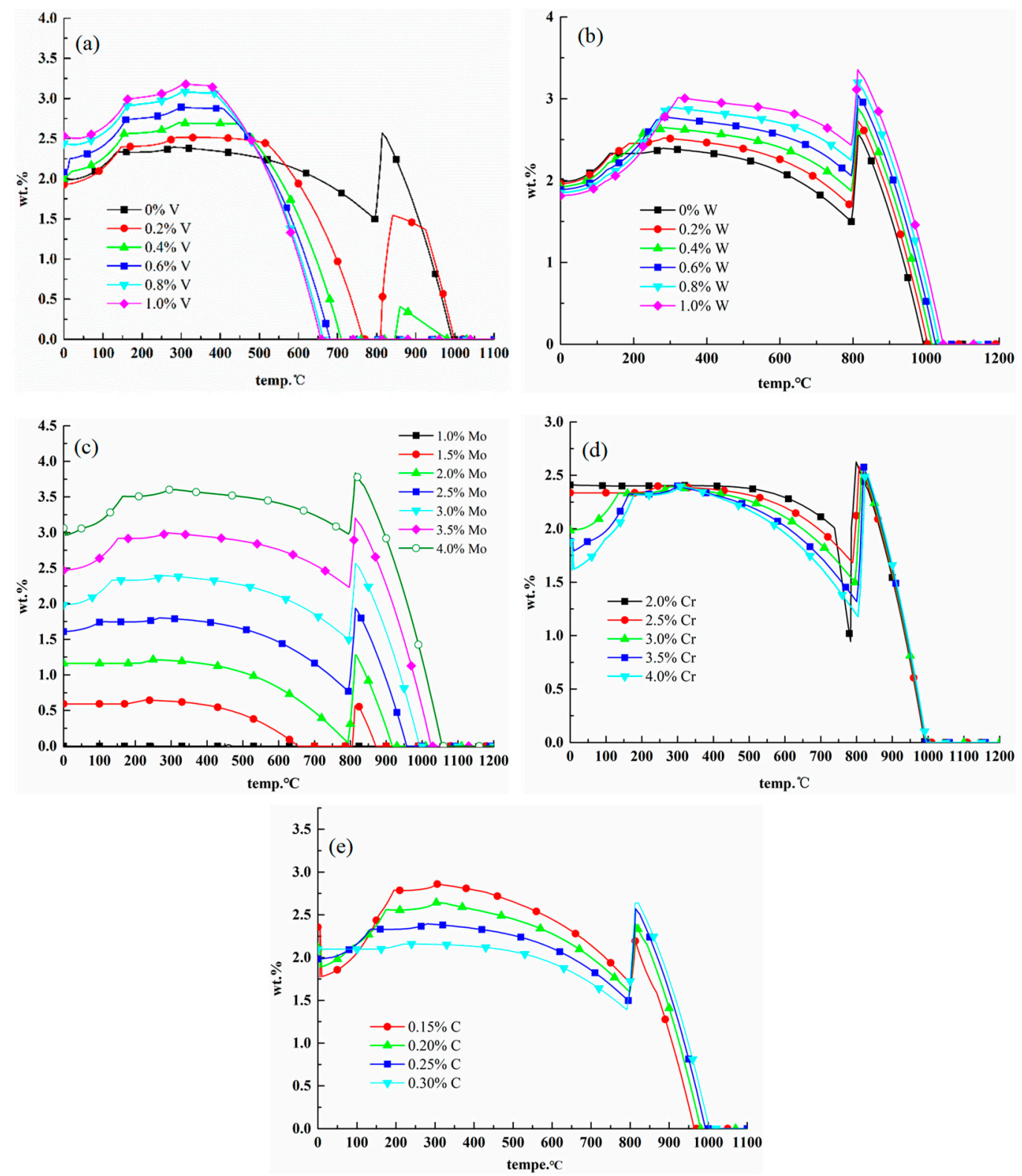

Figure 4. Effects of alloying elements on $\mathrm{M}_{6} \mathrm{C}$ carbides. (a) Effect of $\mathrm{V}$ on $\mathrm{M}_{6} \mathrm{C}$; (b) effect of $\mathrm{W}$ on $\mathrm{M}_{6} \mathrm{C}$; (c) effect of $\mathrm{Mo}$ on $\mathrm{M}_{6} \mathrm{C}$; (d) effect of $\mathrm{Cr}$ on $\mathrm{M}_{6} \mathrm{C}$; (e) effect of $\mathrm{C}$ on $\mathrm{M}_{6} \mathrm{C}$.

\subsubsection{Effects of Elements on MC Carbides}

As shown in Figure 5, V has complex effects on the MC carbides in the material. As can be seen from the calculation results, when the $\mathrm{V}$ content is about $0.4 \%$, the $\mathrm{MC}$ carbide content in the alloy is the highest at about $700{ }^{\circ} \mathrm{C}$. Previous research [16] has shown that the addition of V into the steel can change its carbide type, size and chemical compositions significantly; P. Michaud et al. [17] reported that when the $\mathrm{V}$ content increased from $0.47 \%$ to $0.84 \%$, the precipitation behavior of carbides changed and the amount of nano-scaled carbides would increase substantially. The above results show that the $\mathrm{V}$ content in the steel above $0.4 \%$ can significantly affect the carbide precipitation behavior in the 
alloy, which is consistent with the calculation result. The calculation results are described in Figure 5a. Element $\mathrm{W}$ inhibits MC carbides at all temperatures, as shown in Figure $5 b-d$, show that Mo and Cr elements play important roles in the formation of MC carbides below $1050{ }^{\circ} \mathrm{C}$ and below $800{ }^{\circ} \mathrm{C}$, respectively. $\mathrm{C}$ element can significantly promote the formation of MC-type carbides. The higher the content of $\mathrm{C}$ element, the greater the mass fraction of MC-type carbides in the matrix, and the wider the carbide precipitation temperature range, as shown in Figure 5e.
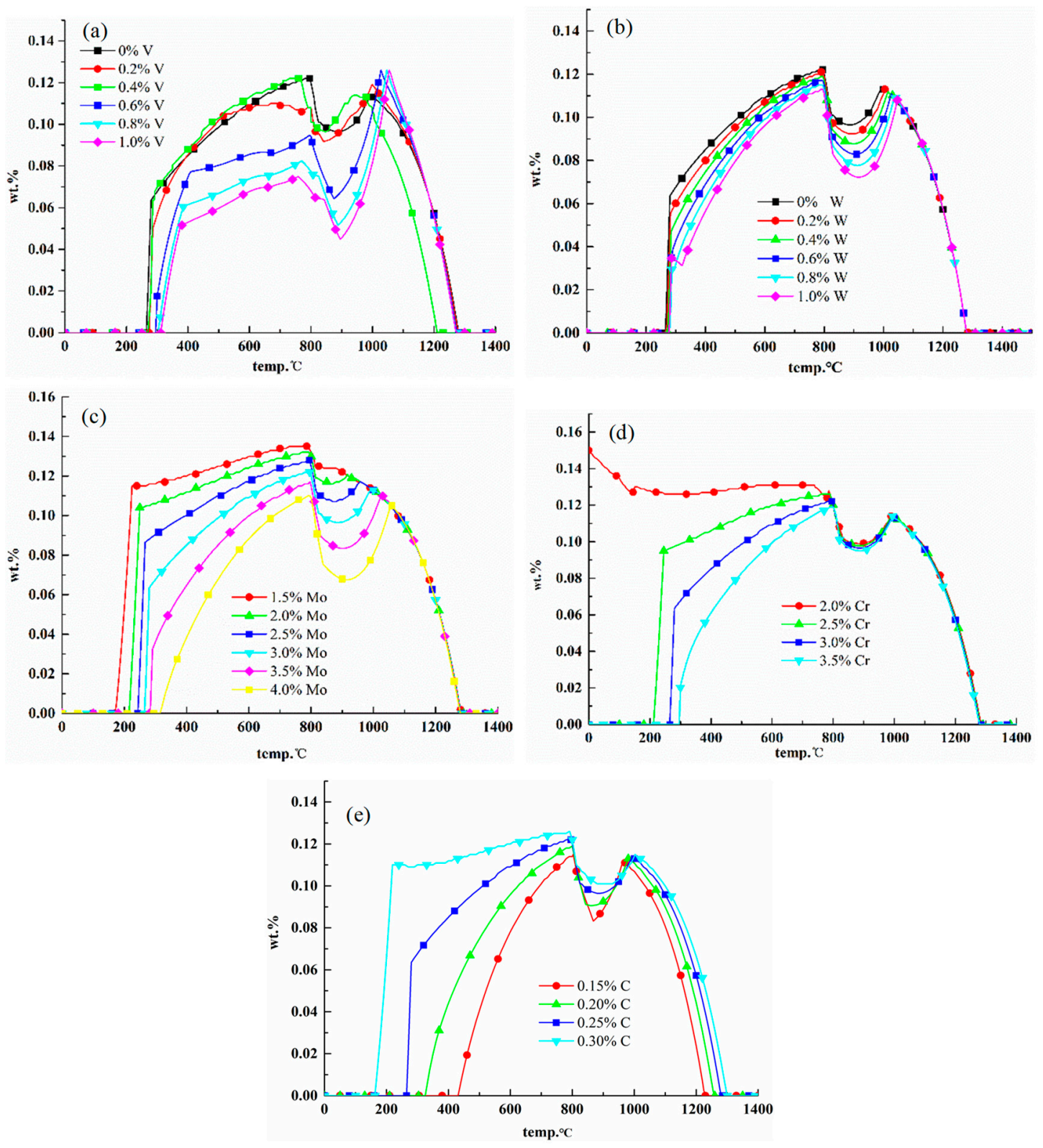

Figure 5. Effects of alloying elements on MC carbides. (a) Effect of $\mathrm{V}$ on MC; (b) effect of $\mathrm{W}$ on MC; (c) effect of Mo on MC; (d) effect of Cr on MC; (e) effect of C on MC.

There are some differences between the simulated carbides and the actual observations results. No $\mathrm{M}_{2} \mathrm{C}$ or $\mathrm{M}_{7} \mathrm{C}_{3}$ carbides can be found in the simulation results. However, $\mathrm{M}_{2} \mathrm{C}$ carbide has been reported to be an important strengthening phase to provide secondary strengthening effects in $\mathrm{Cr}-\mathrm{Mo}-\mathrm{V}$ hot-work die steel. This is because the calculation is based on the equilibrium conditions, and $\mathrm{M}_{2} \mathrm{C}$ and $\mathrm{M}_{7} \mathrm{C}_{3}$ carbides are non-equilibrium phases for $25 \mathrm{Cr} 3 \mathrm{Mo} 3 \mathrm{NiNb}$ steel. If the tempering holding time is extended indefinitely under actual conditions, the experimental results will gradually approach the calculation results. 


\subsubsection{Comparison of Precipitates between $25 \mathrm{Cr} 3 \mathrm{Mo} 2 \mathrm{NiWVNb}$ Steel and $25 \mathrm{Cr} 3 \mathrm{Mo} 3 \mathrm{NiNb}$ Steel}

According to the above calculation results, appropriate reduction of Mo can inhibit the growth of $\mathrm{M}_{2} \mathrm{C}$ and $\mathrm{M}_{6} \mathrm{C}$ carbides. The formation of $\mathrm{M}_{23} \mathrm{C}_{6}$ can be inhibited by reducing $\mathrm{Cr}$ appropriately. Addition of $\mathrm{V}$ and $\mathrm{W}$ can inhibit the formation of $\mathrm{M}_{23} \mathrm{C}_{6}$, improve the morphology and distribution of MC carbides, and increase the $\mathrm{C}$ content slightly, thus increasing the precipitation of carbides and strengthening the strengthening effect of solid solution. The chemical compositions of the new alloy initially were determined by the phase diagram calculations, as shown in Table 5 . The compositions for the equilibrium phase diagram calculation (Figure 6) are $\omega(\mathrm{C})=0.3 \%, \omega(\mathrm{Cr})=2.9 \%, \omega(\mathrm{Ni})=1.4 \%$, $\omega(\mathrm{Mo})=1.8 \%, \omega(\mathrm{W})=0.6 \%, \omega(\mathrm{V})=0.8 \%, \omega(\mathrm{Nb})=0.05 \%$. For the sake of convenience, $25 \mathrm{Cr} 3 \mathrm{Mo} 3 \mathrm{NiNb}$ steel is called "alloy 1", and 25Cr3Mo2NiWVNb steel is called "alloy 2".

Table 5. Preliminarily formulated alloy $25 \mathrm{Cr} 3 \mathrm{Mo} 2 \mathrm{NiWVNb}$ composition range.

\begin{tabular}{cccccccccc}
\hline Elements & $\mathbf{C}$ & $\mathbf{S i}$ & $\mathbf{M n}$ & $\mathbf{N i}$ & $\mathbf{C r}$ & $\mathbf{V}$ & $\mathbf{M o}$ & $\mathbf{W}$ & $\mathbf{N b}$ \\
\hline $\mathrm{wt}^{2} \%$ & $0.27-0.32$ & $\leq 0.10$ & $\leq 0.10$ & $1.3-1.5$ & $2.0-3.0$ & $0.3-1.0$ & $1.5-2.5$ & $0.40-0.70$ & $0.03-0.1$ \\
\hline
\end{tabular}

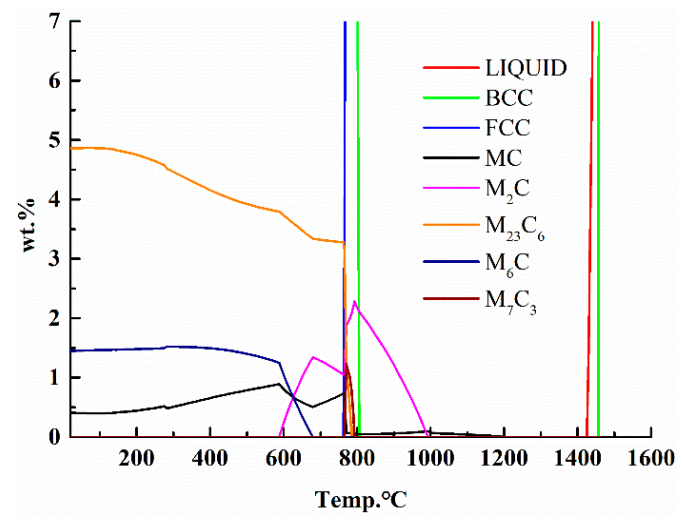

Figure 6. Alloy 2 equilibrium phase diagram.

It can be seen from the calculation results shown in Figure 7 and Table 6 that the content of MC carbides in alloy 2 at $500-700{ }^{\circ} \mathrm{C}$ is significantly higher than that of the comparative material. The $\mathrm{M}_{2} \mathrm{C}$ carbide appears in the calculation result of alloy 2, but it is not reflected in alloy 1 . As long as Mo is added, $\mathrm{M}_{2} \mathrm{C}$ carbide is one of the main strengthening phases of hot-work die steels $[18,19]$. This condition may be caused by the less stability and the lower content of the $\mathrm{M}_{2} \mathrm{C}$ in alloy 1 , which can be regarded as a calculation deviation. From the simulation results, it can be found that the $\mathrm{M}_{23} \mathrm{C}_{6}$ carbide content in the designed material is slightly higher than that of the comparative material below $360{ }^{\circ} \mathrm{C}$. However, with the increase of temperature, the $\mathrm{M}_{23} \mathrm{C}_{6}$ carbide content in the designed material decreases rapidly. This may be related to the decreasing thermal stability of the $\mathrm{M}_{23} \mathrm{C}_{6}$ carbide in the developed material with the alloying elements.

Table 6. Comparing the information calculated from the balance phase of alloy 1 and alloy 2 .

\begin{tabular}{ccccccc}
\hline \multirow{2}{*}{$\begin{array}{c}\text { Balanced } \\
\text { Phase }\end{array}$} & \multicolumn{2}{c}{ 25Cr3Mo3NiNb (Alloy 1) } & \multicolumn{2}{c}{ 25Cr3Mo2NiWVNb (Alloy 2) } \\
\cline { 2 - 7 } & $\begin{array}{c}\text { Content at } \\
\mathbf{5 0 0}{ }^{\circ} \mathbf{C}\end{array}$ & $\begin{array}{c}\text { Content at } \\
\mathbf{6 0 0}{ }^{\circ} \mathbf{C}\end{array}$ & $\begin{array}{c}\text { Content at } \\
\mathbf{7 0 0}{ }^{\circ} \mathbf{C}\end{array}$ & $\begin{array}{c}\text { Content at } \\
\mathbf{5 0 0}{ }^{\circ} \mathbf{C}\end{array}$ & $\begin{array}{c}\text { Content at } \\
\mathbf{6 0 0}{ }^{\circ} \mathbf{C}\end{array}$ & $\begin{array}{c}\text { Content at } \\
\mathbf{7 0 0}{ }^{\circ} \mathbf{C}\end{array}$ \\
\hline $\mathrm{MC}$ & $0.0987 \%$ & $0.109 \%$ & $0.117 \%$ & $0.787 \%$ & $0.81 \%$ & $0.557 \%$ \\
$\mathrm{M}_{6} \mathrm{C}$ & $2.26 \%$ & $2.11 \%$ & $1.85 \%$ & $1.4 \%$ & $1.05 \%$ & $0 \%$ \\
$\mathrm{M}_{23} \mathrm{C}_{6}$ & $3.84 \%$ & $3.91 \%$ & $4.05 \%$ & $3.92 \%$ & $3.73 \%$ & $3.32 \%$ \\
$\mathrm{M}_{2} \mathrm{C}$ & 0 & 0 & 0 & 0 & $0.239 \%$ & $1.283 \%$ \\
\hline
\end{tabular}




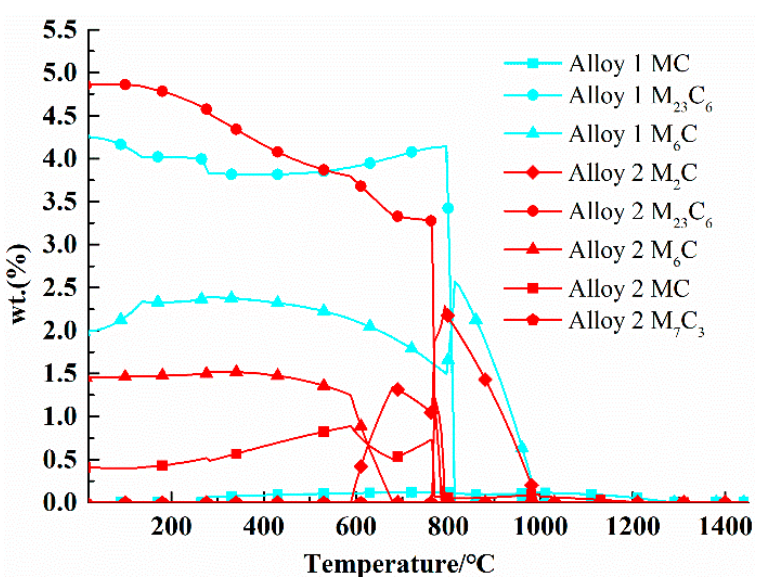

Figure 7. Comparison of carbides—both materials.

\subsection{Microstructure}

\section{TEM Investigations}

Figures 8 and 9 show TEM micrographs of the two types of steel after tempering at $640{ }^{\circ} \mathrm{C}$. Alloy 2 exhibits typical tempered martensite with lath structures and many precipitates, while the lath structures of the comparative material disappear. Figure 10a is a TEM micrograph of a new alloy sample. It shows that a large number of nano-sized short rod-shaped carbides about 5-10 nm long are widely distributed. Similarly, short rod-like carbides are also found in the comparative materials. However, the distribution is less diffuse, and the size is about $80 \mathrm{~nm}$, which is larger than the former.
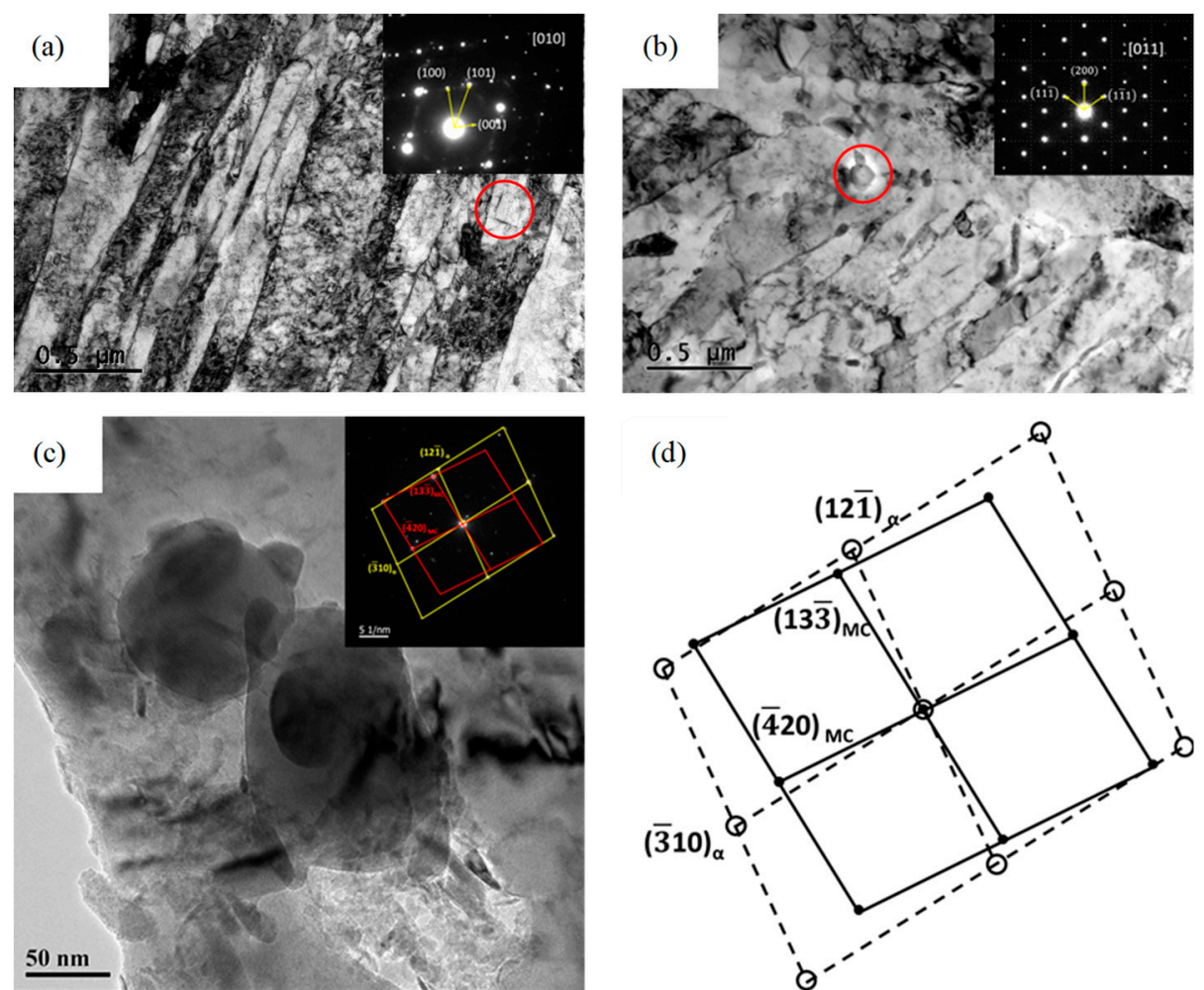

Figure 8. TEM images showing different kinds of precipitates of $25 \mathrm{Cr} 3 \mathrm{Mo} 2 \mathrm{NiWVNb}$ steel after tempering at $640{ }^{\circ} \mathrm{C}$. (a) $\mathrm{M}_{2} \mathrm{C}$; (b) $\mathrm{M}_{6} \mathrm{C}$; (c) MC; (d) the corresponding diffraction pattern of MC. 


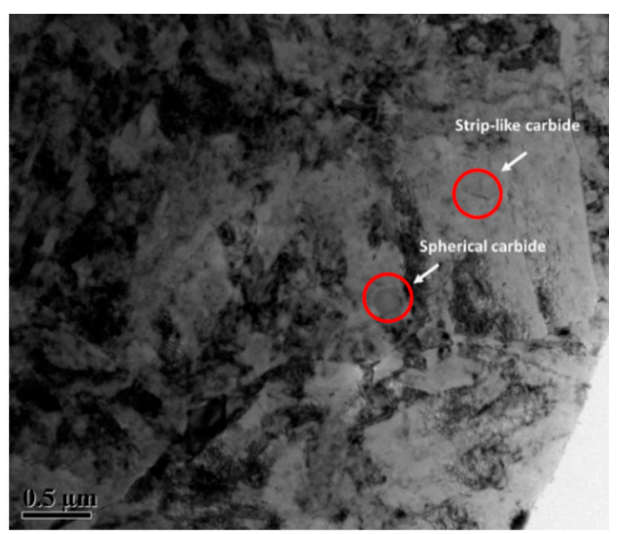

Figure 9. TEM micrographs of two kinds of precipitates in $25 \mathrm{Cr} 3 \mathrm{Mo} 3 \mathrm{NiNb}$ steel after tempering at $640{ }^{\circ} \mathrm{C}$.
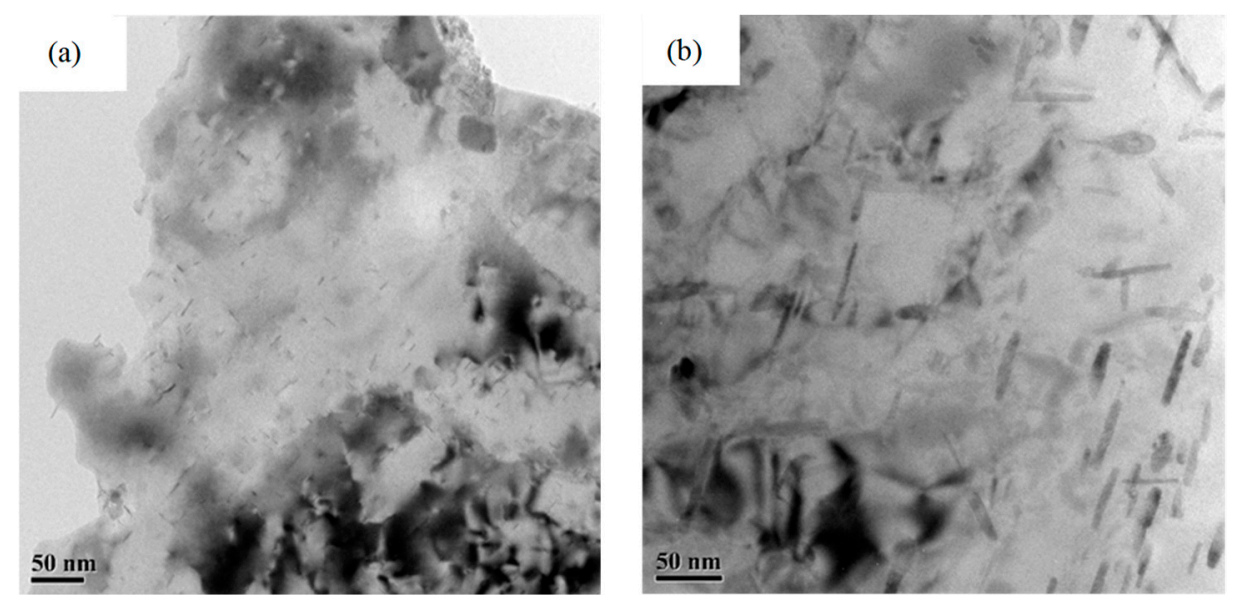

Figure 10. TEM micrographs of two kinds of nano-sized short rod-shaped precipitates in different steels. (a) 25Cr3Mo2NiWVNb steel; (b) 25Cr3Mo3NiNb.

A considerable number of obvious rod-shaped precipitates are observed in the matrices of the two materials. Alloy 2 contains rod-shaped carbides with different diameters (the length is $5-10 \mathrm{~nm}$ and $80-120 \mathrm{~nm}$ respectively), while alloy 1 only contains the rod-shaped carbides with a diameter of $10-20 \mathrm{~nm}$ and a length of about $80 \mathrm{~nm}$. Previous research [19] has revealed that the rod-shaped carbides in $25 \mathrm{Cr} 3 \mathrm{Mo} 3 \mathrm{NiNb}$ are $\mathrm{M}_{2} \mathrm{C}$ carbides. The corresponding SAED (Selected Area Electron Diffraction) spots of alloy 2 are shown in Figure 8. Figure 11 indicates that the larger size rod-shaped carbide is HCP (Hexagonal Close-packed) cubic structure, and the smaller size rod carbide is FCC (Face-centered Cubic) cubic structure. Figure 8a shows a typical diffraction pattern of $\mathrm{M}_{2} \mathrm{C}$ carbides while Figure 11 shows that the smaller size rod carbide is MC carbides. 

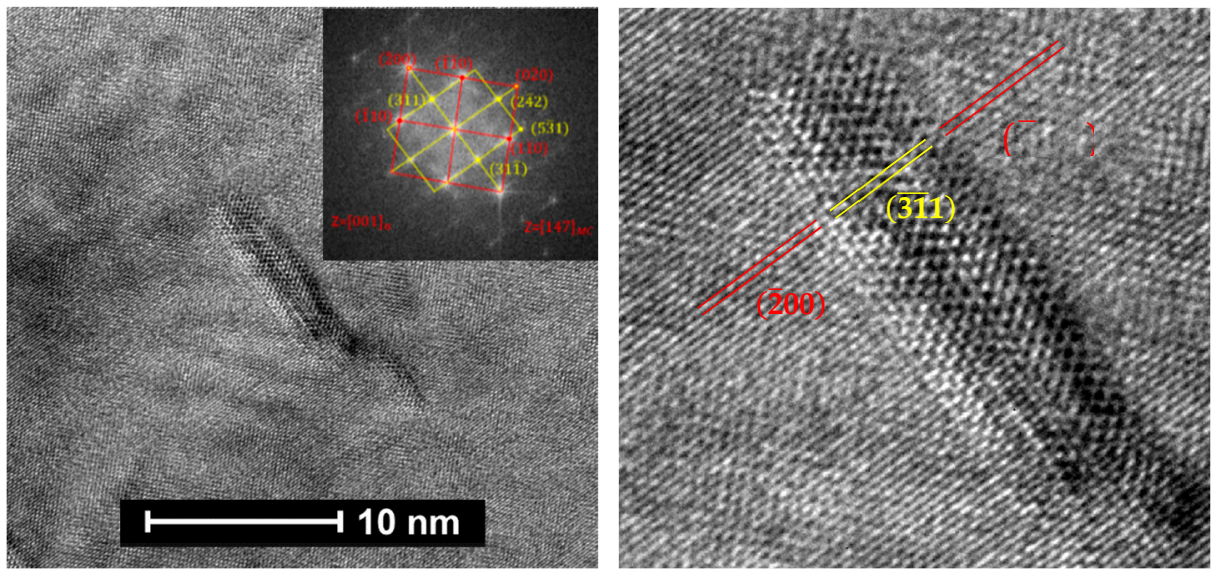

Figure 11. The corresponding SAED pattern of nano-sized short rod-shaped precipitates in 25Cr3Mo2NiWVNb steels.

\subsection{Mechanical Properties}

Table 7 shows the tensile mechanical properties of alloy 1 and alloy 2 after quenching at $1020^{\circ} \mathrm{C}$ and tempering at $640^{\circ} \mathrm{C}$. The result displays that alloy 2 has high hardness, room temperature tensile strength and yield strength. The room temperature tensile strength and yield strength of alloy 2 are about $200 \mathrm{MPa}$ higher than those of alloy 1 . Table 8 gives the high-temperature strength properties. As the experimental temperature increases to $700^{\circ} \mathrm{C}$, the ultimate tensile strength and the yield strength of the experimental steel are significantly reduced, but alloy 2 is about $100 \mathrm{MPa}$ higher than alloy 1 at $700{ }^{\circ} \mathrm{C}$. The high-temperature elongation of alloy 2 is slightly lower than that of alloy 1 .

Table 7. Mechanical properties of alloy 1 and alloy 2 after heat-treatment processes.

\begin{tabular}{ccccc}
\hline Steel & $\begin{array}{c}\text { Ultimate Tensile } \\
\text { Strength/MPa }\end{array}$ & $\begin{array}{c}\text { Yield } \\
\text { Strength/MPa }\end{array}$ & Elongation/\% & Hardness/HRC \\
\hline Alloy 1 & 1180 & 920 & 18.5 & 35.5 \\
Alloy 2 & 1374 & 1178 & 17 & 43 \\
\hline
\end{tabular}

Table 8. High-temperature tensile test properties of two alloys.

\begin{tabular}{ccccc}
\hline Materials & $\begin{array}{c}\text { Test } \\
\text { Temperature } /{ }^{\circ} \mathbf{C}\end{array}$ & $\begin{array}{c}\text { Ultimate Tensile } \\
\text { Strength/MPa }\end{array}$ & $\begin{array}{c}\text { Yield } \\
\text { Strength/MPa }\end{array}$ & Elongation/\% \\
\hline Alloy 1 & 700 & 380 & 277 & 24.0 \\
Alloy 2 & 700 & 495 & 385 & 21.0 \\
\hline
\end{tabular}

\section{Results and Discussion}

During the quenching process, most alloying elements are dissolved back and precipitated on the martensitic matrix in the form of carbides during tempering. The type, size, distribution and stability of carbides precipitated on the tempered martensite matrix determine the mechanical properties of the material. It is well recognized that the $\mathrm{M}_{2} \mathrm{C}$ carbide formed at high temperature has good tempering softening resistance and secondary hardening [19]. Therefore, after tempering at $640{ }^{\circ} \mathrm{C}$ for $2.5 \mathrm{~h}$, alloy 2 still has high hardness and tensile strength. Shi et al. [20] has shown that the stability of $\mathrm{M}_{2} \mathrm{C}$ carbides determines the stability of martensite laths. For example, the DM steel still has martensite shape after tempering at $700{ }^{\circ} \mathrm{C}$. The fine martensite laths provide stronger resistance to dislocation motion than the recrystallized structure. Alloy 2 contains not only a large number of $\mathrm{M}_{2} \mathrm{C}$-type carbides and dispersed nano-sized MC-type carbides, which have outstanding contributions to the thermal stability of lath martensite. Figure 12 shows the microstructure comparison of two materials after stretching at $700{ }^{\circ} \mathrm{C}$. Obviously, alloy 2 still has the apparent martensite lath morphology after stretching at $700{ }^{\circ} \mathrm{C}$, while 
the martensite lath morphology of alloy 1 almost disappears. When the material is deformed at a high temperature, the lath structure and the dispersed carbides effectively hinder the dislocation motion, thus improving the high-temperature strength substantially. Meanwhile, the increase in deformation resistance leads to a small reduction in elongation.
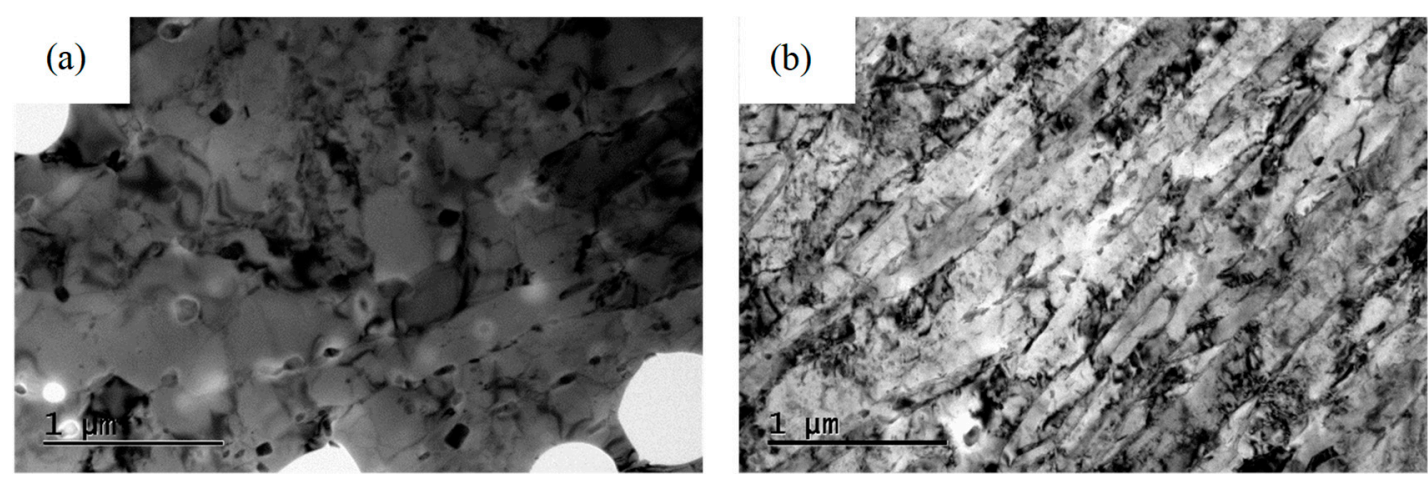

Figure 12. Microstructure comparison of two materials after stretching at $700{ }^{\circ} \mathrm{C}$. (a) Alloy $1 ;$ (b) alloy 2.

It has been reported that the addition of $\mathrm{V}$ can reduce the diffusion of carbon atoms by forming strong carbides in steel [21]. $\mathrm{V}$ is added as a trace element to the alloy, which reduces the diffusion of $\mathrm{C}$, Cr, Mo and Mn atoms [16]. Therefore, fewer C, Cr, Mo, and Mn atoms enter the alloyed carbide, which decreases the size of the carbide. Meanwhile, the reduction in the Mo content further reduces the size of the $\mathrm{M}_{2} \mathrm{C}$ type carbide. Improving alloying elements not only reduces the size of $\mathrm{MC}$ and $\mathrm{M}_{2} \mathrm{C}$ carbides, but also makes the carbides much finer and more dispersed. It can be seen from Figures 10 and 13 that alloy 2 contains a large number of finely dispersed short rod-shaped carbides $\left(\mathrm{M}_{2} \mathrm{C}\right)$, which effectively block the movement of dislocations, lath boundaries and grain boundaries under high-temperature conditions. As a result, the new alloy has a good thermal stability, and the lath martensite morphology is maintained even after a high-temperature tempering [22-24].

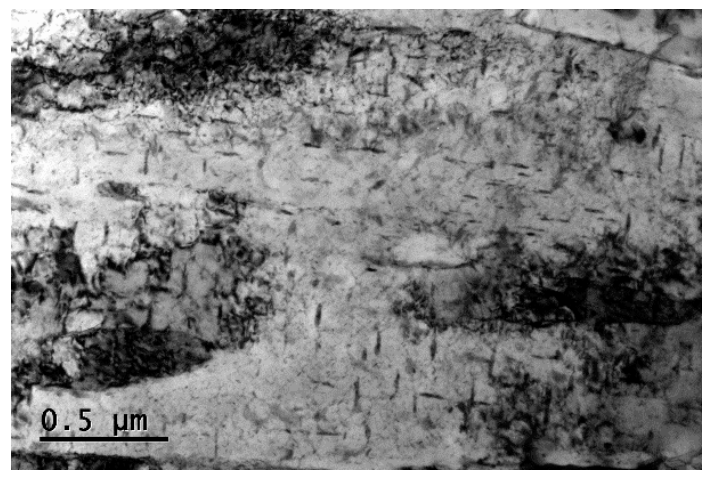

Figure 13. $\mathrm{MC}$ carbides, $\mathrm{M}_{2} \mathrm{C}$ carbides and dislocation groups in alloy 2.

\section{Conclusions}

(1) In order to obtain $\mathrm{MC}$ and $\mathrm{M}_{2} \mathrm{C}$ carbides which are beneficial to thermal stability and high-temperature strength, the contents of $\mathrm{V}$ and $\mathrm{W}$ were increased while the contents of Mo and $\mathrm{Cr}$ were decreased. Meanwhile, Ni was added appropriately to improve the toughness and hardenability of the material.

(2) Based on the thermodynamic calculation, a new material 25Cr3Mo2NiWVNb steel was designed. The new material contains a large amount of nano-sized short rod-shaped $\mathrm{MC}$ and $\mathrm{M}_{2} \mathrm{C}$ carbides (the lengths are 5-10 $\mathrm{nm}$ and 80-120 $\mathrm{nm}$ respectively). In contrast, the traditional material only contains the rod-shaped carbides with a diameter of 10-20 nm and a length about $80 \mathrm{~nm}$. 
(3) The large number of finely dispersed $\mathrm{MC}$ carbides and $\mathrm{M}_{2} \mathrm{C}$ carbides is beneficial for stabilizing martensite lath at high temperatures, which further hinders the dislocation motion at high temperature. The high-temperature strength of the new material is about $30 \%$ higher than that of the traditional material.

Author Contributions: Z.Z.: data analysis, writing; J.Z.: study design; Z.Y.: data analysis; G.X.: data analysis; Y.L.: data collection; M.M.: literature search; C.Z.: figures; J.H.: study design.

Funding: This research received no external funding

Conflicts of Interest: The authors declare no conflict of interest.

\section{References}

1. Gu, J.; Li, J.; Huo, J. Effect of precipitation on hardening and toughening of nitrogen-alloyed H13 steel. Steel Res. Int. 2017, 88, 1700031. [CrossRef]

2. Katoch, S.; Sehgal, R.; Singh, V. Effect of cryogenic treatment on the tribological behaviour of H11 hot die steel dry sliding against D3 steel. Tribol. Mater. Surf. Interfaces 2016, 10, 185-195. [CrossRef]

3. Gu, J.; Li, J.; Chen, Y. Microstructure and strengthening-toughening mechanism of nitrogen-alloyed $4 \mathrm{Cr} 5 \mathrm{Mo} 2 \mathrm{~V}$ hot-working die steel. Metals 2017, 7, 310. [CrossRef]

4. Li, S.; Wu, X.; Chen, S.; Li, J. Wear resistance of H13 and a new hot-work die steel at high temperature. J. Mater. Eng. Perform. 2016, 25, 2993-3006. [CrossRef]

5. Barrau, O.; Boher, C.; Gras, R.; Rezai-Aria, F. Analysis of the friction and wear behaviour of hot work tool steel for forging. Wear 2003, 255, 1444-1454. [CrossRef]

6. Wei, M.X.; Wang, F.; Wang, S.Q.; Cui, X.H. Comparative research on the elevated-temperature wear resistance of a cast hot-working die steel. Mater. Des. 2009, 30, 3608-3614. [CrossRef]

7. Wang, Q.; Yan, Z.; Liu, X.; Dong, Z.; Fang, H. Understanding of fatigue crack growth behavior in welded joint of a new generation Ni-Cr-Mo-V high strength steel. Eng. Fract. Mech. 2018, 194, 224-239. [CrossRef]

8. Schaffner, T.; Hartmaier, A.; Kokotin, V.; Pohl, M. Analysis of hydrogen diffusion and trapping in ultra-high strength steel grades. J. Alloys Compd. 2018, 746, 557-566. [CrossRef]

9. Wang, W.; Wang, K.; Kodur, V.; Wang, B. Mechanical properties of high-strength Q690 steel at elevated temperature. J. Mater. Civ. Eng. 2018, 30, 4018062. [CrossRef]

10. Dong, J.; Zhou, X.; Liu, Y.; Li, C.; Liu, C.; Guo, Q. Carbide precipitation in Nb-V-Ti microalloyed ultra-high strength steel during tempering. Mater. Sci. Eng. A 2017, 683, 215-226. [CrossRef]

11. Wang, B.; Li, Z.; Zhan, D.; Jiang, M. Precipitation behavior of VN in high nitrogen and vanadium micro-alloyed low carbon weathering steel. Trans. Indian Inst. Met. 2018, 71, 1607-1613. [CrossRef]

12. Delagnes, D.; Lamesle, P.; Mathon, M.H.; Mebarki, N.; Levaillant, C. Influence of silicon content on the precipitation of secondary carbides and fatigue properties of a $\% \mathrm{Cr}$ tempered martensitic steel. Mater. Sci. Eng. A 2005, 394, 435-444. [CrossRef]

13. Ishii, R.; Tsuda, Y.; Yamada, M.; Kimura, K. Fine precipitates in high chromium heat resisting steels. Tetsu-to-Hagané 2009, 88, 36-43. [CrossRef]

14. Mebarki, N.; Delagnes, D.; Lamesle, P.; Delmas, F.; Levaillant, C. Relationship between microstructure and mechanical properties of a 5\% Cr tempered martensitic tool steel. Mater. Sci. Eng. A 2004, 387, 171-175. [CrossRef]

15. Wu, D.; Wang, F.; Cheng, J.; Li, C. Effects of $\mathrm{Nb}$ and tempering time on carbide precipitation behavior and mechanical properties of $\mathrm{Cr}-\mathrm{Mo}-\mathrm{V}$ steel for brake discs. Steel Res. Int. 2018, 89, 1700491. [CrossRef]

16. Wen, T.; Hu, X.; Song, Y.; Yan, D.; Rong, L. Carbides and mechanical properties in a Fe-Cr-Ni-Mo high-strength steel with different V contents. Mater. Sci. Eng. A 2013, 588, 201-207. [CrossRef]

17. Michaud, P.; Delagnes, D.; Lamesle, P.; Mathon, M.H.; Levaillant, C. The effect of the addition of alloying elements on carbide precipitation and mechanical properties in 5\% chromium martensitic steels. Acta Mater. 2007, 55, 4877-4889. [CrossRef]

18. Zhou, Q.; Wu, X.; Shi, N.; Li, J.; Min, N. Microstructure evolution and kinetic analysis of DM hot-work die steels during tempering. Mater. Sci. Eng. A 2011, 528, 5696-5700. [CrossRef]

19. Wang, M.; Dong, H.; Wang, Q. Elevated-temperature properties of one long-life high-strength gun steel. Rare Met. 2004, 11, 67. 
20. Shi, Y.J.; Wu, X.C.; Li, J.W.; Min, N. Tempering stability of Fe-Cr-Mo-W-V hot forging die steels. Int. J. Min. Met. Mater. 2017, 24, 1145-1157. [CrossRef]

21. Kelly, A.; Nicholson, R.B. Strengthening Methods in Crystals; Halstead Press Division, John Wiley \& Sons: New York, NY, USA, 1971.

22. Palmiere, E.J.; Garcia, C.I.; Deardo, A.J. The influence of niobium supersaturation in austenite on the static recrystallization behavior of low carbon microalloyed steels. Metall. Mater. Trans. A 1996, 27, 951-960. [CrossRef]

23. Dutta, I.; Bourell, D.L. Influence of dislocation density and distribution on the aging behavior of $6061 \mathrm{Al}$ SiCw composites. Acta Metall. Mater. 1990, 38, 2041-2049. [CrossRef]

24. Rahmanifard, R.; Farhangi, H.; Novinrooz, A.J. Development of mechanical performance of 12YWT steel nanocomposite by addition of zirconium and tantalum. J. Alloys Compd. 2016, 657, 646-654. [CrossRef]

(C) 2019 by the authors. Licensee MDPI, Basel, Switzerland. This article is an open access article distributed under the terms and conditions of the Creative Commons Attribution (CC BY) license (http://creativecommons.org/licenses/by/4.0/). 